JPASDEV

Journal of Public Administration

And Sociology of Development

Vol. 1., N0. 2., Desember 2020

\title{
Efektivitas Implementasi Kebijakan Penanggulangan Bencana Kabut Asap di Kota Pontianak
}

\author{
Arifin $^{1}$ \\ 1. Fisip Universitas Tanjungpura \\ Korespondensi Penulis : idris.arifin@yahoo.com
}

\begin{abstract}
Based on the data found, the policy implementation of disaster management of smoky haze has not been effective in preventing the disaster. It seems effective whenever a disaster occurs. Therefore, the research aims to analyze the policy effectiveness of disaster prevention in Pontianak suburban area. The research method used the qualitative approach to describe the observed object. The research result shows that there are two crucial factors of failure in implementing the policy disaster prevention. The program implementation is focused on the prevention and only a form of response to the disaster. Besides, the program only focuses on the institution building. The local government should actively move to focus on the behavior of communities in a suburban area of Pontianak in implementing the prevention program.
\end{abstract}

Key words : The policy implementation of disaster prevention, smoky haze, Pontianak suburban area 


\section{PENDAHULUAN}

Kota Pontianak selalu mengalami bencana kabut asap setiap tahunnya. Menurut pihak Badan Penanggulangan Bencana Daerah (BPBD) Kota Pontianak terdapat 2 kecamatan sebagai kecamatan yang memproduksi asap dari pembakaran lahan yaitu Kecamatan Pontianak Selatan dan Kecamatan Pontianak Tenggara. Dari kedua Kecamatan tersebut, Kecamatan Pontianak Tenggara yang paling dominan sebagai penyebab kabut asap.

\section{Penyebab utama Bencana} berupa kebakaran hutan lahan gambut yang menyebabkan kabut asap adalah tingkat kesadaran masyarakat yang rendah terhadap pentingnya menjaga kelestarian alam. Pemicu utamah hal ini adalah faktor ekonomi. Pada musim kemarau masyarakat melakukan pembakaran hutan untuk membersihkan lahan perkebunan baru sehingga sering menyebabkan terjadi bencana kebakaran hutan (BPBD Pontianak).

Dalam mengantisipasi hal bencana tersebut, pemerintah Provinsi Kalimantan Barat telah lama membuat larangan pembukaan lahan dengan cara membakar. Dasar aturan yang digulirkan juga sudah cukup tua yaitu Perda N0. 6 Tahun tentang Pencegahan dan Penanggulangan Kebakaran Hutan dan Lahan. Peraturan ini dikeluarkan mengingat seluruh Kabupaten maupun Kota yang ada di Kalimantan Barat pada saat itu merupakan daerah yang memproduksi asap dari pembukaan lahan tersebut. Namun Perda itu seakan-akan belum memberikan efek positip terhadap pelaku pembakar lahan.

\section{Untuk mengatasi masalah} bencana kabut asap ini pula, pada tingkat Pemerintahan Kota (Pemkot) Pontianak juga mengeluarkan kebijakan serupa sebagai langkah antisipasi dalam penangggulangan bencana yang terjadi setiap tahunya.

Berdasarkan tabel 1 dapat dilihat mulai tahun 2017 sampai dengan tahun 2018 jumlah kebakaran lahan dan hutan di Kawasan Kota Pontianak mengalami penurunan dan peningkatan, tidak ada satu tahun pun daerah di Kota Pontianak bebas dari pembakaran lahan. Daerah yang 
JPASDEV

Journal of Public Administration

And Sociology of Development

Vol. 1., N0. 2., Desember 2020

terbakar di katakan cukup besar dari tahun ke tahun seperti terlihat pada tahun 2017 sampai 3,45 hektar dikatakan luas walaupun diikuti daerah Kubu Raya tetapi masih didominasi oleh Daerah Kota Pontianak.

Kebakaran lahan yang cukup merata tersebut merupakan faktor penyebab terjadinya kabut asap di Pontianak. Selain itu, pada tahun 2018 jumlah area yang terbakar termasuk kecil dibandingkan dengan tahun tahun sebelumnya, area yang terbakar meliputi kawasan Pontianak saja.

Pernyataan dari pihak Penanggulangan Bencana Daerah (BPBD) Kota Pontianak menyatakan bahwa terlihat 2 kawasan kecamatan yang setiap tahun selalu memproduksi asap dari pembakaran lahan yang dilakukan yaitu Kecamatan Pontianak Selatan dan Pontianak Tenggara. Namun setiap tahunnya Kecamatan Pontianak Tenggara yang masih dominan dalam membakar lahan.
Tabel 1, Kebakaran Lahan/ Hutan

Kota Pontianak 2017 s/d 2018

\begin{tabular}{|c|c|c|c|c|}
\hline \multirow{2}{*}{$\begin{array}{c}\text { Tah } \\
\text { un }\end{array}$} & \multicolumn{4}{|c|}{ Uraian } \\
\hline & $\begin{array}{c}\text { Luas } \\
\text { area } \\
\text { yang } \\
\text { terba } \\
\text { kar }\end{array}$ & $\begin{array}{l}\text { Juml } \\
\text { ah } \\
\text { korb } \\
\text { an }\end{array}$ & \multicolumn{2}{|c|}{ Jumlah lokasi yang terbakar } \\
\hline $\begin{array}{c}20 \\
17\end{array}$ & $\begin{array}{c}34.5 \\
00 \\
\mathrm{~m} 2 \\
(3,45 \\
\mathrm{Ha})\end{array}$ & 0 & $\begin{array}{l}7 \\
\text { Lok } \\
\text { asi }\end{array}$ & $\begin{array}{l}\text { 1. Ptk Sel } 2 \text { kali } \\
\text { 2. Ptk Tenggara } 3 \text { kali } \\
\text { 3. Kubu Raya } 2 \text { kali }\end{array}$ \\
\hline $\begin{array}{c}201 \\
8\end{array}$ & $\begin{array}{c}56.6 \\
00 \\
\mathrm{~m} 2 \\
(5,7 \\
\mathrm{Ha})\end{array}$ & 0 & $\begin{array}{l}12 \\
\text { Lok } \\
\text { asi }\end{array}$ & $\begin{array}{l}\text { 1. Ptk Sel } 5 \text { kali } \\
\text { 2. Ptk Tenggara } 6 \text { kali } \\
\text { 3. Kubu Raya } 1 \text { kali }\end{array}$ \\
\hline \multicolumn{3}{|c|}{ Jumlah } & & 19 kali \\
\hline
\end{tabular}

Sumber: Badan Penanggulangan Bencana Daerah (BPBD) Kota Pontianak (September, 2018)

Beranjak dari permasalahan di atas, peneliti membatasi permasalahan pada bagaimana pengimplementasiaan kebijakan yang telah dikeluarkan oleh Pemerintah Kota Pontianak dalam penyelenggaraan penanggulangan bencana kabut asap di wilayah pinggiran kota Pontianak.

Pada paradigma lama, penanganan bencana merupakan fungsi tunggal pemerintah dalam melindungi masyarakat. Pemerintah diharapkan oleh masyarakat dapat melaksanakan penanganan bencana tersebut secara penuh karena pemerintah itu dianggap oleh 
JPASDEV

Journal of Public Administration

And Sociology of Development

Vol. 1., N0. 2., Desember 2020

masyarakat mempunyai dana dan aparat yang banyak, kelembagaan atau institusi tersebar di mana-mana, serta kekuatan-kekuatan lainnya pada pemerintah.

Pada paradigma baru penanggulangan bencana merupakan pelibatan beberapa pihak secara aktif yaitu pemerintah, masyarakat, serta lembaga/organisasi baik daerah atau nasional. Dalam konteks di atas, maka penelitian yang berkaitan dengan bencana merupakan penelitian yang kompleks yaitu masalahnya tidak bisa dipandang pada satu aspek/satu sisi saja melainkan dari berbagai aspek.

Dari uraian di atas, peneliti merumuskan tujuan khusus dari penelitian ini sejauh mana efektivitas kebijakan penanggulangan kebakaran hutan (kabut asap) di kota Pontinak. Ada beberapa faktor yang membuat penelitian yang berkaitan dengan masalah bencana di wilayah pinggiran kota Pontianak di pandang urgen.

Pertama, wilayah pinggian kota Pontianak merupakan salah satu wilayah berpotensi mengalami bencana kebakaran hutan. Kebakaran ini disebabkan kondisi hutan yang tidak terjaga sehingga dimanfaatkan oleh masyarakat secara tidak bertanggungjawab. Selain itu, adanya ancaman lain berupa bencana ini kalau tidak ditanggulangi secara dini memungkinkan semakin besar dan berakibat fatal untuk di kemudian hari.

Urgensi yang kedua adalah sebagaimana dinyatakan oleh Abidin (2006) kemampuan daerah terutama kapasitas daerah perlu diperkuat karena lembaga daerah sebagai garda pertama dalam menghadapi bencana baik itu pada tahapan pengindenfikasian dampak bencana, edukasi public, penataan ruang, serta serta respons bencana.

Berdasarkan observasi hasil wawancara dengan pihak BPBD Pontianak diperoleh informasi bahwa kemampuan yang dimiliki kota Pontianak dalam penanganan /penanggulangan bencana kurang maksimal yang disebabkan koordinasi dengan pihak terkait terutama lembagai/institusi berwenang ataupun dengan masyarakat masih sangat kurang. Dalam hal ini, kajian yang mendalam berkaitan dengan masalah ini adalah dianggap hal yang 
JPASDEV

Journal of Public Administration

And Sociology of Development

Vol. 1., N0. 2., Desember 2020

mendasar.

Urgensi yang ketiga adalah berbagai kendala lain yang dihadapi dalam penanggulangan bencana yang terjadi di kota Pontianak seperti hambatan birokrasi, keterbatasan SDM, dana dan prasarana. Menurut sumber dari BPBD Pontianak mengatakan bahwa masih adanya tumpang tindih peran antar instansi pemerintah sehingga penanggulangan bencana kurang efektif Demikian juga SDM dan prasarana serta dana yang disediakan oleh pemerintah dalam penanggulangan/penanganan masalah kebencanaan masih sangat minim.

Keempat, belum adanya kebijakan yang menyeluruh dan terpadu yang mengatur masalah penanggulangan bencana di Kota Pontianak. Sewaktu peneliti mewawancarai pihak BPBD Pontianak untuk meminta peraturan daerah sebagai turunan dari Undang-Undang Republik Indonesia N0. 24 Tahun 2007 tentang Penanggulangan Bencana masih belum dapat ditemukan. Pihak BPBD Pontianak hanya menyediakan Perwa (Peraturan Walikota) yang berkaitan dengan penanggulangan bencana. Setelah peneliti mencermati Perwa yang dikeluarkan tersebut, baik tindakan serta kebijakan esensinya masih bersifat parsial atau sepotongsepotong yang tidak menyeluruh dan terpadu antara unit yang satu dengan unit yang lain.

Keluaran yang dihasilkan dari kegiatan ini berupa pemetaan permasalahan secara komprehensif serta hasil kajian dengan rekomendasi mengenai penanggulangan bencana kebakaran lahan gambut (kabut asap) di wilayah pinggiran kota Pontianak.

\section{METODE PENELITIAN}

Penelitian ini dengan menggunakan Pendekatan kualitatif yang bersifat deskriptif analisis untuk menggambarkan sedalam-dalamnya efektivitas dalam pengimplementasi kebijakan penanggulanggan kebakaran hutan atau kabut asap. Lokasi penelitian difokuskan pada Pontianak Tenggara dengan alasan pemicu terbakarnya lahan dengan karakteristik yang unik yaitu kebakaran yang terjadi akibat ketidaksengajaan warga setempat. 


\section{HASIL DAN PEMBAHASAN}

Kecamatan Pontianak Tenggara dengan luas $10,91 \mathrm{Km}^{2}$ yang terdiri atas 4 kelurahan meliputi Kelurahan Bangka Belitung Laut dengan luas 2,33 $\mathrm{Km}^{2}$ atau sekitar 15,64 persen, dengan diikuti Kelurahan Bangka Belitung Darat dengan luas 2,90 $\mathrm{Km}^{2}$ atau sekitar 19,45 persen, Kelurahan Bansir Laut 2,95 $\mathrm{Km}^{2}$ atau sekitar 19,78 persen dan Kelurahan Bansir Darat $6,73 \mathrm{Km}^{2}$ atau sekitar 45,14 persen.

Sungai Raya Dalam atau daerah sekitar kecamatan Pontianak Tenggara pinggiran merupakan wilayah yang sering dilanda kabut asap terutama daerah Sugai Raya Dalam yang berbataasan dengan Kabupaten Kubu Raya. Sungai Raya Dalam merupakan daerah yang menjadi pusat lokasi penelitian Karena wilayah ini merupakan daerah dengan intensitas kabut asap yang tinggi.

Berdasarkan sumber yang didapat dari pihak BPBD (Badan Penanggulangan Bencana Daerah ) Pontianak bahwa potensi kabut asap yang melanda Kota Pontianak tidak hanya bersumber pada pusat kota namun berasal dari kiriman dari daerah lainnya, seperti yang tampak pada daerah-daerah yang berbatasan dengan Kabupaten Kubu Raya. Sebagaimana diketahui bahwa Kabupaten Kubu Raya merupakan salah satu kabupaten dengan kerawanan kabut asap ketika musim kemarau yang besar.

Berhasilnya implementasi kebijakan yang berkaitan dengan penanggulangan bencana kabut asap yang terjadi khususnya di wilayah pinggiran kota Pontianak banyak dipengaruhi oleh beberapa aspek. Aspek-aspek yang mempengaruhi implementasi kebijakan baik ukuran dan kebijakan, komunikasi, sumber daya, disposisi, karakteristik agen pelaksana, lingkungan, serta aspekaspek lainnya.

Menurut Edward III (1984), beberapa aspek yang mempengaruhi efektif tidaknya suatu kebijakan yaitu aspek komunikasi, sumberdaya, disposisi, serta struktur organisasi. Pada aspek komunikasi ada tiga hal yang perlu diperhatikan yaitu konsistensi, kejelasan, serta bagaimana mentransmisikan kebijakan.

Pada aspek komunikasi, salah 
JPASDEV

Journal of Public Administration

And Sociology of Development

Vol. 1., N0. 2., Desember 2020

satu bentuk yang dilakukan adalah dengan dilakukannya sosialisasi Perwa peraturan walikota) yang berkaitan dengan masalah penanggulangan bencana atau peraturan lain yang berlaku secara nasional yaitu UU No.24 Tahun 2007 tentang Penanggulangan Bencana.

Seperti yang dipaparkan oleh ketua BPBD bahwa Latar belakang pembentukan BDBP Kota Pontianak merupakan Lembaga Khusus yang masih memiliki peran sangat penting dan strategis dalam upaya penanggulangan bencana di daerah mulai dari pra bencana, tanggap darurat dan pasca bencana. Sosialisasi dalam penanggulangan bencana ini dilaksanakan tidak hanya secara serimonial, namun harus menunjukkan komitmen dan kepedulian terhadap upaya penanganan bencana khususnya dalam wilayah kota Pontianak yang mungkin akan terjadi baik disebabkan oleh faktor alam, faktor non alam maupun faktor ulah manusia yang berakibat dapat menimbulkan korban jiwa maupun kerusakan lingkungan, kerugian harta benda dan dampak psikologi.
Selanjutnya beliau mengungkapkan bahwa penanganan bencana merupakan tanggung jawab bersama dan oleh karenanya perlu dijalin hubungan kerjasama dan koordinasi strategis pihak terkait sesuai kewenangan agar bertindak secara cepat, tepat dan terpadu sehingga dapat memberikan perlindungan kepada masyarakat yang terkena dampak bencana. Disamping itu pula semua stakeholdeer dapat melakukan penanganan secara sinergis dan selaras serta membentuk posko pada lokasi kejadian, sehingga bencana yang timbul segera dapat ditangani dan tidak menimbulkan korban jiwa yang lebih besar.

Adapun sosialisasi yang dilakukan lanjut beliau dengan beberapa hal yang perlu mendapatkan perhatian yaitu : 1. Melalui sosialisasi ini dapat dijadikan salah satu awal perubahan diri untuk meningkatkan koordinasi antara instansi// lembaga terkait lainnya dalam mengatasi penanganan bencana. 2. Sosialisasi peningkatkan kebersamaan dan satu arah komando dalam penanganan bencana. 3, sosialisasi melalui koordinasi dalam menyaatukan 
JPASDEV

Journal of Public Administration

And Sociology of Development

Vol. 1., N0. 2., Desember 2020

persepsi untuk bertindak dalam penanggulangan bencana. 4. Serta aktivitas sosialisasi yang diharapkan kepada masyarat dapat mengikuti kegiatan sosialisasi dengan penuh kesungguhan sehingga nantinya dapat diimplementasikan pada penanganan bencana.

Selain itu, untuk kedepannya lanjut beliau sasaran sosialisasi akan lebih meningkatkan kemitraan dan kolaborasi dalam penyelenggaraan penanggulangan bencana. Kemitraan dan kolaborasi ini mencakup para pelaku penanggulangan bencana, termasuk pemerintah - pusat dan daerah - masyarakat, lembaga usaha, lembaga non pemerintah, dan lembaga internasional."

Selanjutnya beliau menegaskan bahwa dalam menjalankan kemitraan dan kolaborasi penanggulangan bencana itu meliputi deklarasi, komitmen, perencanaan, penganggaran, implementasi, umpan balik, serta pemantauan dan evaluasi. Untuk pendanaan tahap pertama adalah pendanaan yang berasal dari pemerintah saja. Tahap kedua adalah pendanaan dari pemerintah dan lembaga usaha. Tahap yang paling bagus adalah ketika pendanaan berasal dari pemerintah, lembaga usaha, masyarakat dan lembaga-lembaga donor.

Dari paparan di atas jelas bahwa sosialisasi yang dilakukan untuk dapat meningkatkan kesadaran masyarakat serta pada akhirnya terbentuk kemitraan yag bersinergis antara masyarakat dan pihak pemerintah.

Namun, dalam hal ini peneliti menginterview beberapa informan yang menyatakan bahwa sosialisasi atau komuikasi yang dilakukan oleh pihak pemerintah secara khusus belum dilakukan secara intensif. Masyarakat lebih banyak menyerap informasi dari media local dan nasional yang berkaitan dengan kebencanaan tersebut.

Komuikasi yang dilakukan oleh pihak pemerintah belumlah menyeluruh kepada masyarakat yang berada di daerah rawan bencana. Hanya sebagian masyarakat saja yang berinteraksi dengan pihak pemerintah.

Berdasarkan pengamatan 
JPASDEV

Journal of Public Administration

And Sociology of Development

Vol. 1., N0. 2., Desember 2020

peneliti bahwa terlihat disudut-sudut jalan yang bertuliskan peringatan dalam pelarangan membakar hutan atau membakar sampah disembarang tempat. Namun setelah dikonfirmasi kepada masyarakat apakah komukasi yang dilakukan sudah menyentuh masyarakat ternyata bagi sebagian masyarakat tidak sepenuhnya melihat dan memperhatikan komunikasi dalam bentuk baliho tersebut.

Pernyataan masyarakat yang
penting bagi peneliti adalah
masyarakat menghendaki adanya
tindak lanjut yang nyata dari
sosialisasi yang diadakan serta
sosialisai tersebut hendaknya
dilakukan secara menyeluruh.

Berdasarkan hasil wawancara dari pihak BPBD bahwa walaupun daerah bukan sawah di Pontianak Tenggara tersebut relative masih kecil namun penggunaan yang semestinya seperinya di atas masih belum optimal. Sehingga lahan tersebut tidak terlalu dimanfaatkan oleh masyarakat secara maksimal. Namun pada saat musim kemarau, lahan bukan pertanian tersebut menjadi lahan yang rawan terbakar yang disebabkan oleh perilaku masyrakat yang senang membakar sampah sembarangan. Selain itu lahan tersebut karena mudah dibakar pada musim kemarau, masyarakat memanfaatkan lahan tersebut sebagai kebun, terutama kebun jagung, mayarakat pada umumnya membakar lahan tersebut untuk dijadikan lahan perkebunan sementara.

Berdasarkan penjelasan dari Kasi Pencegahan Dan Kesiapsiagaan Badan Penanggulangan Bencana Daerah (BPBD) Kota Pontianak bahwa :

"Dalam menanggulangi bencana, BPBD biasanya mendapatkan SK dari walikota. SK inilah kita turun ke lapangan dan menyurati beberapa instansi yang ada di kota Pontianak agar tanggap darurat bencana" (Hasil wawancara pada Oktober 2018)

Hal yang serupa juga dikemukakan oleh Sekretaris Badan Penanggulangan Bencana Daerah (BPBD) Kota Pontianak bahwa :

"Biasanya ketika terjadi bencana, kita mendapatkan SK dari pak walikota. Dan untuk memudahkan 
JPASDEV

Journal of Public Administration

And Sociology of Development

Vol. 1., N0. 2., Desember 2020

saat kami bekerja, kami biasanya membuat surat edaran ke beberapa instansi lainnya. Hal ini bertujuan ketika bencana terjadi mereka siap membantu kita dalam menanggulangi bencana" (Hasil wawancara pada Oktober 2018)

Secara umum, informasi yang didapatkan pada masyarakat Kota Pontianak Tenggara pinggiran bahwa mereka mengolah lahan pertaian dengan cara membakar lahan pertanian tersebut ketika musim kemarau. Lahan pertanian tersebut baik ditanami sayursayuran, tanaman padi dan palawija serta jenis tanaman lainnya.

Menurut masyarakat bahwa pertanian yang dilakukan kalau lahan yang diolah itu tepat pada musim kemarau maka masyarakat akan membakar lahan sebagai pembersiahan lahan (land clearing).

Beranjak dari pernyataan di atas dapat, pihak BPBD sedikit menyimpulkan bahwa lahan pertanian atau aktitivitas pertanian meruspakan salah satu kontribusi yang terbesar penyebab kabut asap yang terjadi di Kota Pontianak.
Berikut ini tinjauan umum yang berkaitan dengan hasil pertanian yang dianggap sebagai salah penyumbang kabut asap di Kota Pontianak. Pada tahun 2017 prduksi tanaman padi menghasilkan 40,60 ton dengan rata produksi 29,00 $\mathrm{kw} / \mathrm{ha}$ selain itu produksi tanaman palawija terbagnyak aaah tanaman ubi kayu sebesar 262,50 ton diikuti ubi rambat 112,50 ton.

Tanaman sayur-sayuran, tampak bahwa tanaman kangkung, petsai /sawi merupakan komoditi dominan dengan produksi masingmasing sebesar 330 kuintal dan 256 kuintal. Produksi buah-buahan terbanyak adsalah nangka/cempedak adalah 82 kuintal, disusul tanaman mangga sebanyak 39 kuintal.

Berdasarkan data di atas, dapat dikatakan juga bahwa adanya korelasi implicit bahwa semakin tinggi hasil pertanian masyarakat maka tingkat kontribusi kabut asap akan semakin tinggi pula terutama pada saat kemarau.

Selain factor tersebut, factor penduduk juga mempengaruhi penyumbang kabut asap di Pinggiran 
JPASDEV

Journal of Public Administration

And Sociology of Development

Vol. 1., N0. 2., Desember 2020

Pontianak Tenggara. Secara rinci, jumlah pendududk kecamatan Pontianak Tenggara tahun 2011 berjumlah 45.753 jiwa yang terdiri atas penduduk laki-laki 22.371 jiwa atau 48,90 persen dan penduduk perempuan 23,382 jiwa atau 51,10 persen yang tersebuar di empat kelurahan.

Berdasarkan data di atas terlihat bahwa terjadi ketimpangan jumlah penduduk di satu kelurahan dan kelurahan lainnya. Di sini terlihat bahwa kelurahan yang berada di pinggiran kota dengan kepadatan penduduk yang rendah di bandingkan dengan kepadatan penduduk yang berada di pusat kota.

Adapun dampak dari ketimpangan ini, berdasarkan observasi bahwa daerah pinggiran yang relative berpenduduk jarang memudahkan warganya dalam membuang sampah di sembarang tempat. Wilayah yang berpenduduk jarang ini, pada umumnya masih masih berupa semak belukar. Di sisi semak belukar tersebut peneliti biasa lihat beberapa bungkusan-bungkusan sampah yang dibuang oleh warga.
Demikian juga terkadang di daerah pinggiran semak tersebut menumpuk gundukan sampah yang dibuat oleh masyarakat. Gundukan sampah ini yang kemudian dibakar oleh oleh warga sebagai akibat dari sumber asap.

Kondisi di atas tersebut, disinyalir bahwa masyarakat yang membuat sampah di pinggiran semak tidak hanya masyarakat setempat namun masyarakat yang tinggal diperumahan yang menjadikan pinggiran semak-semak di daerah pinggiran Kecamatan Pontianak sebagai tempat pembuangan sampah. Hal ini mereka lakukan karena fasilias penampungan sampah di perumahan terkadang tidak tersedia.

Penyebab lain adalah banyaknya lahan terlantar yang tidak dirawat oleh pemiliknya. Lahan lahan tersebut banyak tersebar di pinggiran kota Pontianak. Salah satu kasus yang terjadi salah satu lahan warga yang terbakar yaitu di daerah Kubu Raya yang berdampingan dengan Sungai Raya Dalam. Lahan tersebut terutama lahan gambut.

Kebakaran di lahan gambut tersebut berdasarkan informasi warga 
JPASDEV

Journal of Public Administration

And Sociology of Development

Vol. 1., N0. 2., Desember 2020

yang tidak jauh dari lokasi kejadian pasti terjadi pada musim kemarau yang menyebabkan munculnya asap tebal di wilayah tersebut. Kebakaran biasaya terjadi di daerah pemukiman warga, seperti yang tampak pada gambar kebakaran lahan yang mendekati perumahan warga. Api yang susah dipadamkan membuat warga yang berdekatan dengan sumber api tersebut dapat mengakibatkan kepanikan namun masyarakat setempat secara bekerjasama dalam mematikan lahan yang terbakar tersebut.

Salah satu warga yang bernama Warno (50), warga yang berdekatan dengan lahan yang terbakar mengatakan terbakarnya lahan tersebut selalu terjadi pada musim kemarau dan ssangat disayangkan dirasakan petugas pemadam kebakaran atau yang badan lainnya kurang tanggap. Warno sendiri tidak tahu bahwa tanah yang terbakar tersebut merupakan tanah kaplingan atau tidak, namun pemiliknya tidak diketahui secara pasti.

Menurut pantauan bahwa dalam mencegah meluasnya kebakaran lahan, petugas UPKHL Dinas Kehutanan Kalbar menerjunkan satu regu petugas dengan dua unit alat pemadam kebakaran. Menurut Kepala Seksi Mobilisasi Kebakaran Hutan dan Lahan Dinas Kehutanan Kalbar, Sriyanto, untuk di wilayah Kalbar terutama daerah pinggiran seperti Kubu Raya dan Sungai Raya Dalam terdapat beberapa titik api yang terjadi.

Selain aspek komunikasi aspek sumber daya merupakan aspek penting dalam pencapaian keberhasilan pengimplemenasian kebijakan. Sumberdaya yang sangat diperlukan dalam penanganan kabut asap tersebut yang dirasakan kurang yaitu petugas serta biaya operasional. Seperti yang dikemukakan oleh pihak BPBD yaitu:

"Untuk kawasan Kota Pontianak dalam menanggulangi bencana kabut asap kalau dari BPBD Kota Pontianak saja tidaklah cukup. (Oktober, 2018).

Berdasarkan hasil wawancara tersebut ditegaskan bahwa dalam menanggulangi bencana terutama bencana kabut asap tidaklah cukup dari pelaksana saja. Faktor penting lain adalah peran serta pihak yang terkait langsung, baik itu Lembaga Swadaya Masyarakat, serta masyarakat setempat 
yang terdekat. Dari itulah dukungan relawan sangat diperlukan, hal ini juga dipertegas dengan hasil wawancara kepala pelaksana BPBD Kota Pontianak ,mengungkapkan bahwa:

"Saat bencana kabut asap terjadi walaupun jumlah anggaota atau personil BPBD ini minim, tapi kita mendapatkan bantuan dari relawan yang ada di kota Pontianak, baik itu dari pemadam kebakaran swasta, dari relawan yang secara sukarela ikut membantu." (Oktober 2018).

Terkait dengan informasi tersebut, berdasarkan temuan penulis dilapangan mengenai yang diungkapkan kepala pelaksana Badan Penanggulangan Bencana Daerah (BPBD) Kota Pontianak.

Berikut ini data yang berhubungan dengan jumlah personil yang ada di BPBD Pontianak.
Tabel 3.1. Sumber Daya Manusia BPBD

\begin{tabular}{|c|c|c|c|c|c|c|}
\hline $\begin{array}{c}\text { N } \\
\text { o }\end{array}$ & \multicolumn{2}{|c|}{ Gol. } & \multicolumn{2}{c|}{ Pend. } & \multicolumn{2}{c|}{$\begin{array}{c}\text { Jenis } \\
\text { Kelamin }\end{array}$} \\
\hline 1 & I & 4 & S2 & 3 & Pria & 37 \\
\hline 2 & II & 16 & S1 & 17 & Wanta & 8 \\
\hline 3 & III & 20 & Diploma & 4 & & \\
\hline 4 & IV & 5 & Sma & 16 & & \\
\hline 5 & & & SMP & 4 & & \\
\hline 6 & & & SD & 1 & & \\
\hline & $\begin{array}{c}\text { Jml } \\
\text { ah }\end{array}$ & 45 & Jumlah & 45 & Jmlah & .4 \\
\end{tabular}

Sumber : BPBD Pontianak,2018

Berdasarkan table 4.1 di atas dapat dilihat bahwa sumber daya yang ada di BPBD Pontianak dapat dikatakan memadai dikarenakan jumlah tersebut jika dimanfaatkan semaksimal mungkin dapat berperan sebagai coordinator penanggulangan bencana. Namun, dengan jumlah tersebut masih dirasakan kurang oleh pihak BPBD dikarenakan jumlah bencana pada masa tertentu memerlukan jumlah sumber daya yang banyak.

Dalam hal sumberdaya manusia Jumlah pelaksana harus sesuai dengan kualitas para personil. Hal tersebut juga dipertegas oleh Sekretaris Badan Penanggulangan Bencana Daerah (BPBD) Kota Pontianak,bahwa:

"personil disini sudah dibekali oleh pengetahuan mengenai mengatasi bencana, bahkan setiap adanya 
JPASDEV

Journal of Public Administration

And Sociology of Development

Vol. 1., N0. 2., Desember 2020

kegiatan pelatihan kami mengirim perwakilan kami untuk mengikuti pelatihan ke luar Kalimantan. Setelah selesai pengetahuan yang didapat tersebut kemudian di ajarkan ke kawan lainnya bahkan ke relawan kita. (Oktober, 2018).

Data tersebut menunjukan bahwa dalam penanggulangan bencana yang diperlukan adalah kompetensi pelaksana di lapangan. Kompetensi pelaksana ini dapat mengimbangi jumlah pelaksana yang kurang memadai. Aspek lain yang diperlukan yaitu sumber daya kebijakan (policy resources). Aspek ini dapat memperlancara administrasi dalam pengimplementasian sebuah program.

Aspek selanjutnya adalah aspek disposisi. Demikian juga dengan disposisi yang merupakan adalah watak dan karakteristik atau sikap yang dimiliki oleh implementor seperti komitmen, kejujuran, sifat demokratis. Apabila implementor memiliki disposisi yang baik, maka dia akan dapat menjalankan kebijakan dengan baik seperti apa yang diinginkan oleh pembuat kebijakan. Ketika implementor memiliki sifat atau perspektif yang berbeda dengan pembuat kebijakan, maka proses implementasi kebijakan juga menjadi tidak efektif.

Disposisi ini merupakan aspek yang terkait dengan sikap dan komitmen dalam pelaksanaan program. Sikap dan komitment yang baik akan berakibat pelaksanaan kebijakan itu akan berjalan dengan baik pula, namun sebaliknya.

Selain itu, cakupan atau luas wilayah menjadi pertimbangan penting dalam menentukan agen pelaksana kebijakan.

\section{SOP (Standard Operational Procedur)}

Selain itu, cakupan atau luas wilayah menjadi pertimbangan penting dalam menentukan agen pelaksana kebijakan.

1. SOP (Standar Operational Prosedur)

Dalam melaksanakan suatu kebijakan yang berasal dari pemerintah. Di butuhkan adanya suatu standar pelayanan yang harus ditaati oleh implementor. Standar Operational Prosedur (SOP) didalam 
JPASDEV

Journal of Public Administration

And Sociology of Development

Vol. 1., N0. 2., Desember 2020

melaksanakan

kebijakan

penanggulangan bencana kabut asap.

sudah sangat jelas dan harus di patuhi

oleh pelaksana dalam menanggulangi bencana.

\section{Fragmentasi}

Dalam pelaksaan suatu program, selalu terdapat

peyebaran

tanggungjawab di antara unit/instansi.

Pada penelitian ini ditemui pihak kecamatan sebagai pelaksana pendamping yang berperan maksimal.

Pihak BPBD dan pihak kecamatan dapat bekerjasama dengan baik pada pihak lainnya. Berdasarkan wawancara dengan pengamat bencana yang menyatakan bahwa:

“ Untuk tanggung jawab dalam penanggulangan bencana kabut asap dalam hal ini sudah diatur oleh pemerintah, dalam konteks ini adalah tanggung jawab dari BPBD. Tapi saya pikir bencana kabut asap ini bukan tanggung jawab BPBD saja melainkan kita semua. BPBD diberi kewenangan untuk melakukan koordinasi kepada TNI, Polisi, Satpol PP, pihak kecamatan, kelurahan, dan masyarakat. (Oktober, 2018).
Aspek penting yang lain adalah struktur birokrasi. Sebagaimana organisasi pemerintah yang lain, BPBD mempunyai struktur organisasi yang jelas. Walaupun Struktur organisasi dengan SOP yang dibentuk itu sudah jelas namun ada beberpa hal yang patut diperhatikan dalam memperlancar pelayanan bencana.

Hasil wawancara yang dilakukan, pihak pemerintah mengatakan bahwa berdasarkan pedoman kerja peraturan hukum kedepan BPBD Pontianakan Kota akan selalu berbenah dalam meningkatkan kinerja organisasi. Langkah-langkah yang akan diambil oleh lembaga untuk mewujudkan upaya penanggulangan yang efektif, yaitu :

Peningkatan dan pengembangan aspek kepemimpinan sesuai dengan amanah UU kebencanaan.

Perbaikan akuntabilitas pelaksanaan penanggulangan bencana untuk menuju kepada good governance.

Peningkatan kuantitas dan kualitas SDM pelaksana untuk 
mewujudkan standar pelayanan minimal.

Pelaksanaan evaluasi setiap pelaksanaan penanggulangan kebencanaan.

Selanjutanya pihak BPBD menegaskan bahwa arah penanganan kebencanaan dilaksanakan dengan memadukan berbabgai upaya penanganan dan mitigasi risiko kebencanaan secara menyeluruh dan sistematis dengan melibahkan berbagai pihak dengan komitmen yang telah disepakati bersama,

Kemudian ditambahkan bahwa dalam mensikapi turunan peraturan yang dikeluarkan yaitu PP no.21 tahun 2008 tentang penyelenggaraan penanggulangan bencana dan PP no.22 tahun 2008 tentang pendanaan dn pengelolaan bantuan, serta PP no.23 tahun 2008 tentang pengaturan peran serta lembaga asing non-asing pemeritnah dalam penanggulangan bencana maka hal penting yang perlu diutamakan adalah pemenuhak hak dasar masyarakat dalam rangka mendukung pembangunan aspek kemanusiaan.
Selanjutnya ditegaskan bahwa upaya penanggulangan bencana, diperlukan suatu penanganan yang sistematis dan menyeluruh. Upaya tersebut belum bisa dilakuksan secara maksimal karena masih terdapat beberapa kendala yaitu 1. Sarana dan prasana yang kurang mendukung, 2. Banyak pihak yang masih belum sadar terhadap resiko bencana terutama pada kesiapsiagaan dalam menghadapi bencana. $u$ : (1) Belum memadainya kinerja aparat dan sarana prasarana penanggulangan bencana; (2) Masih rendahnya kesadaran dan pemahaman terhadap resiko bencana dan pemahaman terhadap kesiapsiagaan dalam menghadapi bencana.

Dalam pelaksanaan suatu keadaan tanggap darurat permasalahan yang dihadapi adalah : (1) Koordinasi yang masih rendah antara pemerintah desa dengan pemerintah daerah dalam rangka pendataan terhadap masyarakat yang terdampak akibat bencana; (2) Sarana dan Prasarana yang belum memadai dalam upaya komprehensif penanggulangan bencana;

Aspek penting lain dalam pengamatan peneliti adalah adanya 
JPASDEV

Journal of Public Administration

And Sociology of Development

Vol. 1., N0. 2., Desember 2020

koordinasi dan kerjasama yang baik antara unit yang satu dengan unit yang lainnya. Sebagaimana yang diungkapkan olehh Edward III (1984) bahwa aspek penting dalam keberhasilan implementasi kebijakan adalah sttruktur birokrasi yang dapat mendukung kerjasama dengan pihak lain.

Untuk membangun kerjasasama dan kemitraan dengan berbagai pihak diperlukan SDM yang baik. SDM tersebut harus mampu mengkomunikasikan dan berimprovisasi dalam mengimplementasikan kebijakan untuk mencapai keefektivan suatu program.

Dari itulah sangat diperlukan untuk meningkatkan sumberdaya manusia yang terampil dalam melakukan upaya-upaya preventif dan penanggulangan bencana. Karena upaya yang dilakukan oleh sumber daya manusia tidak hanya terfokus kepada alam namun terfokus juga kepada aspek manusianya.

Pada temuan di lapangan, ada aspek mendasar yaitu kekurangan dalam hal pengimplementasian kebijakan penanggulangan bencara kabut asap yaitu perencanaan yang kurang yang dilakukan oleh BPBD. Tindakan-tindakan ke depan sebagai antisipasi kebencaan yang berkaitan dengan kabut asap masih belum terlihat jelas.

Kenyataan di lapangan, BPBD hanya melakukan penanggulangan pada saat bencana terjadi. BPBD mengerahkan sumberdaya yang ada dalam memadamkan titik-titik api pada daerah bencana kabut asap. Menurut peneliti berdasarkan pengamatan di lapangan, kekurangan penanggulangan bencana yang dilakukan adalah tidak melibatkan masyarakat setempat dalam memadamkan titik-titik api di lokasi.

Masyarakat setempat seharusnya dilibatkan dalam memadamkan titiktitik api sehinggga secara tidak langsung akan memberikan pembelajaran bagi masyarakat terhadap penanggulangan bencana yang dihadapi.

Hal di atas inilah yang menurut peneliti sangat kurang yang dilakukan oleh pihak BPBD sebagai upaya mensinergiskan kegiatan antara pemerintah dan masyarakat. 
JPASDEV

Journal of Public Administration

And Sociology of Development

Vol. 1., N0. 2., Desember 2020

Selain upaya yang bersifat preventif, secara umum yang perlu adalah adanya upaya-upaya yang sifatnya represif. Tentunya upayaupaya tersebut dikoordinasikan secara baik dengan pemerintah. Menurut BNPB, beberapa contoh upaya-upaya tersebebut adalah;

$>$ Pelaksanaan tindakan daerau yang mengutamakan keselamatan.

Pembentukan Posko-posko penanggulangan bencana.

$>$ Pemetaan yang komprehensif terhadap berbagai kemungkinan yang potensial dalam menimbulkan bencana.

$>$ Peningkatan program-program rehabilitasi, baik fisik, sosial, dan ekonomi.

Penciptaan program yang terkait kebencanaan sebagai tindakan preventif.

\section{Secara}

umum,

pengimplementasian kebijakan

kebencanaan masih belum efektiv secara maksima. Penanggulangan kebencanaan masih bersifat uapay tanggap daerurat ketika terjadi bencana,misalnya yang terlihat di saat- saat musim kemarau denan titik-titik api yang tersebar di beberapa wilayah Kecamatan Pontianak Tenggara pinggiran.

\section{Sehingga penanggulangan} bencana tersebut tidak maksimal. Selain tidak fokus, program-program yang dibuat setiap tahun lebih banyak berbentuk respon daripada pengurangan risiko. Misalnya, kegiatan monitoring daerah rawan bencana. Selain itu, program daerah baru sebatas penguatan institusi penanggulangan bencana. Anggaran yang dialokasikan masih kurang memadai. Jumlah yang kecil tersebut tentu masih jauh daripada pembiayaan dalam penanggulangan kebencanaan yang terjadi.

Permasalahan lain yang diamati peneliti adalah, pelimpahan kewenangan dari pemerintah pusat kepada pemerintah daerah seringkali tidak diiringi dengan pengalihan tanggung jawab pelayanan dan perlindungan kepada rakyat. Akibatnya pada saat bencana kabut asap terjadi, tanggapan pemerintah daerah cenderung lambat dan seringkali mengharapkan tanggapan 
langsung dari pemerintah pusat. Di lain pihak, pada saat bencana, kurangnya koordinasi antar tataran pemerintahan menghambat pemberian tanggapan yang cepat, optimal, dan efektif.

\section{SIMPULAN DAN REKOMENDASI}

\subsection{Simpulan}

Beranjak dari kebijakan yang dikeluarkan oleh Walikota Pontianak tentang Penanggulangan Bencana terdapat dua faktor yang menentukan yaitu keadaan sosial ekonommi masyakarat dan komunikasi antara lembaga dan masyarakat. Kedua faktor ini sebagai penentu utama efektif tidaknya dalam pengimplementasian kebijakan kebencanaan.

Terdapat dua faktor penghambaat utama dalam pemicu bencana kabut asap yaitu keterisoliran lokasi, serta perilaku masyarakat yang tidak memperhatikan lingkungan.

\subsection{Rekomendasi.}

Dalam penanggulan bencana aspek perilaku masyarakat merupakan aspek yang tidak bisa diabaikan karena memainkan peran penting dalam upaya pencegahan bencana. Aspek perilaku masyarakat seharusnya diperhatikan secara serius sebagai tindakan preventif dalam upaya pengimplementasian kebijakan yang berorienttasi kepada pencapaian hasil yang tepat sasaran.

Pemerintah sebagai actor utama dalam pengimplementasi kebijakan seharusnya melakukan upaya-upaya koordinatif yang baik antara unit yang satu dengan unit yang lain baik di level daerah dan pusat sehingga dalam pengimplementasian penanggulangan bencana kabut asap dapat diatasi secara menyeluruh.

\section{Referensi}

Abidin, H. ( 2006). Peningkatan Kapasitas Daerah dalam Mitigasi Bencana. ITB.

Bridgman, P. dan Glyn, D. (2004), The Australian Policy Handbook, Crows Nest: Allen and Unwin.

Badjuri, A. dan Teguh, Y. (2003). Kebijakan Publik: Konsep dan Strategi., Semarang: Fisip Undip

Edward III, G. C. (1984). Public Policy Implementing. Jai Press Inc. Londong-England

Nurjanah., ( 2012) . Manajemen Bencana. Bandung: Alfabeta

Sarosa, S. (2012). Penelitian Kualitatif: Dasar-Dasar. Jakarta: Indeks. 
JPASDEV

Journal of Public Administration

And Sociology of Development

Strauss, A., dan Juliet, C. (2003). Dasar-Dasar Penelitian Kualitatif, Yogyakarta: Pustaka Pelajar.

Suryabrata, S., 92012). Metodologi Penelitian. Jakarta; Rajawali Pers.

Sugiyono. (2005). Memahami Penelitian Kualitatif. Bandung; Alfabeta.

Rustan, A. dan Ferry, F.,(2011). Ancaman Bencana dan Kebijakan Penanggulangan di Daerah. Jakarta: LAN

Winarto, B. (200). , Kebijakan Publik: Teori dan Proses. Jakarta:

Medpress.

Widodo, J. (2006). Analisis Kebijakan Publik. Malang: Bayu Media 2008. Analisis Kebijakan Publik Konsep dan Aplikasi Analisis Proses Kebijakan Publik. Malang: Bayu Media

Wira, W. Pengaruh Manajemen Bencana. Dalam http://eprint.ui.ac.id.

\section{Dokumen Perundang-undangan}

UU No.24 Tahun 2007 tentang Penanggulangan Bencana

Peraturan Daerah Kota Pontianak No.17 Tahun 2013 tentang Penyelenggaraan Penanggulangan Bencana 